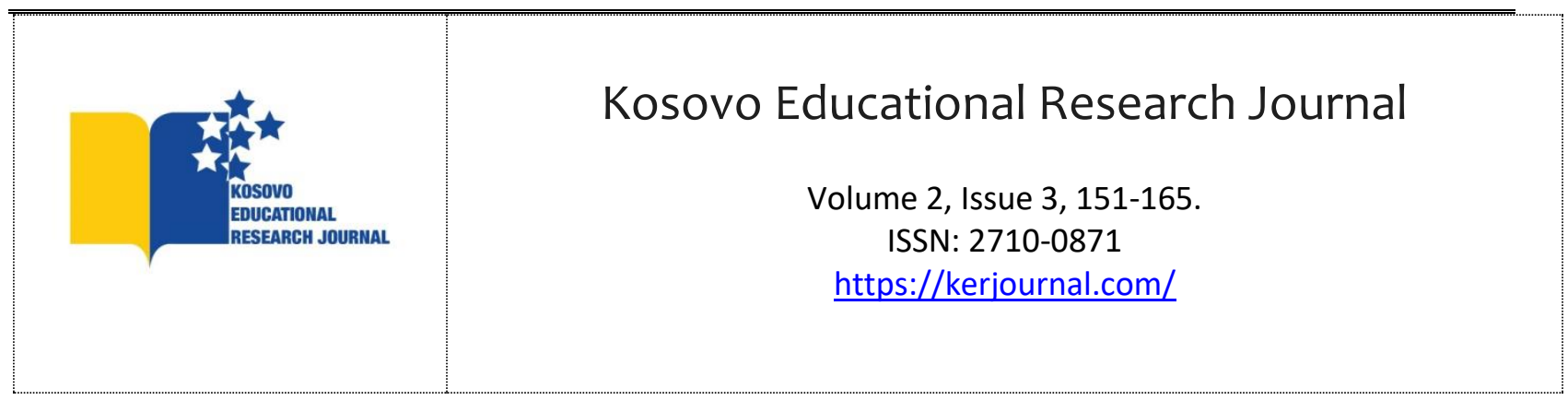

\title{
Covid-19 Pandemi Sürecinde Velilerin Gözünden İlkokul Öğrencileri Nisa KURTEŞ
}

\author{
Prizren Ukshin Hoti Üniversitesi
}

\begin{abstract}
Özet: Covid-19 pandemisi dünyanın tüm düzenini, günlük yaşantısını olumsuz yönde etkilemesinin yanı sıra bizlerin sosyokültürel, politik, ekonomik ve eğitim alanlarında zorlu süreçten geçmemize neden oldu. Salgın nedeniyle Kosova dahil dünya üzerinde 191 ülkede okullar kapatılmış, derslerin uzaktan eğitimle devam edilmesi kararı alınmıştır. Bu durum eğitim öğretimi her yönüyle etkilemiştir. Bu nedenle Covid-19 pandemi sürecinde velilerin gözünden ilkokul öğrencilerindeki davranışların araştırılması amaçlanmıştır. Araştırma tarama modelinde betimsel bir çalışmadır. Çalışma nicel bir çalışma olarak tasarlanmıştır. Veriler Covid-19 pandemisi sürecinde, mesafe kurallarına uygun bir şekilde toplanmıştır. Araştırmanın evrenini 2020-2021 eğitim öğretim yılında, Priştine, Prizren, Priştine, Mamuşa merkezlerinde bulunan "Abdyl Frasheri (PZ)", "Emin Durak (PZ), Mustafa Baki (PZ), Elena Gjika (PR), Anadolu (MA)” Eğitim Bakanlığına Bağlı İlköğretim Okullarında Türkçe eğitim gören öğrencilerin velileri ile yapılmıştır. Örneklem ise 1. 2. 3. 4. ve 5. sınıf öğrencilerinin velileri dahil edilmiştir. Toplamda 153 veliye anket uygulanmıştır. Veliler verilen online eğitimin asla yüzyüze yapılan eğitimin yerini almayacağının kanaatine vardılar. Online eğitimin öğrencilere sağladığı avantajların, sağladıkları dezavantajlara nazaren daha az olduğu düşünülüyor. Veliler covid-19 pandemisi sürecinde çocukların dijital araçları gereğinden fazla kullandıklarını belirtti. Bunun nedenleri sorulduğunda ise evde sıkıldıkları, sokağa çıkma yasağı, arkadaşlarını uzun süre görememeleri gibi birçok nedenin olduğunu dile getirdiler. Pandemi dolayısıyla eğitimin, uzaktan olması gerektiği düşünülse de çoğunluk tarafından ilkokul ve özellikle 1. ve 2. sınıfların yüzyüze eğitim alması gerektiği düşünülmüştür. Bunun sebebi ise okula daha yeni başlamış ve yaşları çok küçük olan öğrencilerin daha yeni yeni okuma ve yazma öğrendikleri için online eğitimin, gerek teknolojik araçları kullanmakta zorluk çekmeleri olsun, gerek çalışan ailelerin her zaman çocuklarının başlarında olamamaları olsun yeterli olmadığı düşünülmüştür. Covid-19 pandemisi ve dolayısıyla da sokağa çıkma yasağı, öğrenciler ve velilerin her zamankinden daha fazla bir süreyi evde geçirmelerine ve bu süreçte de aile bağlarının güçlenmesine yol açtı. Bu bağ covid-19' un onlara getirdiği en pozitif etkilerden biri olarak görülmektedir.
\end{abstract}

Anahtar Kelimeler: Pandemi, Eğitim, Öğrenci 
To cite this article: Kurteş, N. (2021). Covid-19 Pandemi Sürecinde Velilerin Gözünden İlkokul Öğrencileri. Kosovo Educational Research Journal, 2(3). 151-165.

\section{Giriș}

Çin'in Hubei eyaletinin Vuhan şehrinde, önceden bilinmemiş bir hastalık ortaya çıktı. Bu hastalık ağır ve ölümcül bir hastalıktı. Aşısı uzun süre bulunmadı ve diğer ülkelere hızlıca yayılmaya başladı. Bu hastalık tüm dünyayı tehdit etti ve tehtid etmeye ediyor. Bu pandemi ile ilgili vakaların \%20`si ağır, \%5 `i ise kritik hasta olarak kategori edilmiştir (Yalçın, 2020). Bu sebeple, dünyadaki birçok hükümet, vatandaşları için zorla tecrit, sokağa çıkma yasağı, sosyal mesafe gibi ciddi önlemler almıştır (Andrews ve ark., 2020). Covid-19 pandemisi dünyanın tüm düzenini, günlük yaşantısını olumsuz yönde etkilemesinin yanı sıra bizlerin sosyokültürel, politik, ekonomik ve eğitim alanlarında zorlu süreçten geçmemize neden oldu. Sağlık sektörü sonrasında en fazla etkilenen sektörlerin başında eğitim gelmektedir (Telli-Yamamoto ve Altun, 2020; Macit, 2020; Üstün ve Özçiftçi, 2020; TÜBA, 2020). Bu bağlamda Dünya genelinde ekonomi, sağlık, eğitim gibi birçok alanda önleyici faaliyetler uygulanmaya başlanmıştır. Dünya genelinde mesafenin koruması gerekçesiyle dersler online üzerinden yürütülmesi gerektiği öne sürüldü ve dersler uzun bir süre online olarak yürütüldü. Bu süreçte aniden uzaktan eğitime geçildiğinden canlı ders yazılımının önemi ortaya çıkmıştır. Uzaktan eğitim; fırsat eşitsizliğine çözüm getiren, isteyen bireylere yaşam boyu eğitim sağlayan, eğitim teknolojilerinden yararlanmaya dayalı öğrenme uygulamaları olarak ifade edilmektedir (Kaya, 2002, s. 9). Uzaktan eğitim; akademik açıdan öğrencilerin çalışmalarını sürdürebilmesi (Doğan ve Koçak, 2020, s. 121), sosyal ortamlarından kopmaması, zaman yönünden ekonomik olması (Fidan, 2020, s. 30), bireysel öğrenmeyi sağlaması, bireye öğrenme sorumluluğu kazandırması (Kaya, 2002, s. 20) yönünden avantajlar sağlamaktadır. Salgın nedeniyle dünya üzerinde 191 ülkede okullar kapatılmış, derslerin uzaktan eğitimle devam edilmesi kararı alınmıştır.

\section{Kuramsal Çerçeve}

\subsection{Kosova'da Covid-19}

13 Mart 2020 tarihinde Kosova Sağlık Bakanı Arben Vitia, 2 kişide ilk kez Kovid-19'a rastlandığını söyledi. Vitia, virüse yakalananların 20 yaşında bir İtalyan vatandaşı ile 77 yaşında bir Kosovalı olduğunu bildirdi. Kosova Hükûmeti, bu iki şehri karantinaya almaya ve bu iki şehrin 
giriş ve çıkışlarını engellemeye karar verdi. Kosova Hükümeti’nin ilk tepkisi, Ministria e Shënndëtesis dhe Mbrojtjes Sociale -Sağlık ve Sosyal Koruma Bakanlı̆̆g- (2020)'de ilan ettiği 12 Nisan 2020'de medya yoluyla duyurduğu sokağa çıkma yasağı kararı olmuştur. Birçok tedbir, kısıtlama ve başka yasakları da içeren bu kararın ilk maddesi, eğitim sistemiyle doğrudan ilişkili olacak şekilde, okulların kapatılması üzerine olmuştur.

\subsection{Kosovada Online Eğitim}

\section{Kosova'da okulların kapatılması ve uzaktan (online) eğitimin düzenlenmesi.}

Eğitim, Bilim, Teknoloji ve Yenilik Bakanlığının Covid-19 pandemi sürecinde aldığı kararlar:

\section{Mart 2020}

COVID-19 pandemisi sonucu oluşan durum nedeniyle Eğitim, Bilim, Teknoloji ve Yenilik Bakanlığı (EBTB) uzaktan eğitim sürecini (Online) düzenlemek için derhal çalışmalara başlatmıştır.

\section{Mart 2020}

Bakan Bayrami, 1-5. sınıflar için yarın 23 Mart 2020'de başlayacak olan uzaktan eğitim hakkında konuştuğu bir basın toplantısı düzenledi.

\section{Mart 2020}

COVID - 19 pandemisi sonucunda ortaya çıkan durum nedeniyle Eğitim, Bilim, Teknoloji ve Yenilik Bakanlığı, öğretim materyalleri üreterek uzaktan eğitim sürecini organize etmek için çalışmalara başlamıştır. Bu öğretim materyalleri, kamu televizyonu RTK1 ve RTK4'te (yeniden yayın) yayınlanacak ve ayrıca resmi web sitesi https://emesimi.rks-gov.net aracılığıyla halka duyurulacaktır.

\section{Mart 2020}

COVID-19 pandemisinin bir sonucu olarak ortaya çıkan durum nedeniyle, Eğitim, Bilim, Teknoloji ve Yenilik Bakanlığı (EBTB), öğretim materyalleri üreterek uzaktan eğitim sürecini organize etme çalışmalarına başlamıştır.

EBTB, 1-9. sınıflar için öğretim ünitelerinin çekimlerine devam etti. Uzaktan eğitim için içerik hazırlama süreci şimdiden büyük bir hızla ilerliyor. 
1-5. sınıflar için 4 konu için öğretim içerikleri hazırlanmaktadır.

6. sinıf ( 8 ders) için.

7-9. sınıflar için (9 dersten).

Türkçe ve Boşnakça dillerinde de video dersler üretmeye başladık.

Pazartesiden itibaren ders 1-9. sınıflar, dil ve matematik için yayınlanırken, 6 Nisan'dan itibaren tüm sınıflar için tüm derslerin \%70'inden fazlasını içeren çok daha yoğun bir yayınımız olacak. Bunun aracılı̆̆ıyla Youtube'daki MEST kanalına gidiyor.

\section{Ağustos 2020}

Eğitim ve Bilim Bakanı Ramë Likaj bugün 2020/2021 yeni öğretim yılı hazırlıkları ve Covid-19 salgını koşullarında öğretim organizasyonu hakkında Parlamento Eğitim Komitesine rapor verdi. bir önceki tebliğde de açıklanan üç senaryo içeren öğrenme organizasyonu için ana planı ayrıntılı olarak sunmuşlardır:

Senaryo A, önleyici tedbirlerle anaokullarında ve okullarda yüz yüze öğretimi öngörmektedir. Senaryo B, okullara kısmi dönüşü veya okullarda yüzyüze öğretim ve uzaktan eğitimin birleştirilmesini öngörmektedir. Senaryo C uzaktan öğrenmeyi öngörmektedir.

\section{Eylül 2020}

Okul öncesi düzeyi ve 1,2,3,6 ve 10. sınıfları içeren birinci aşama, senaryo A'ya göre (okul varlığ ile) 14 Eylül Pazartesi günü öğretime başlarken, 4. ve 5. sınıflar aynı tarihte öğretime başlar. MED ve okul düzeyinde görev gücünün değerlendirmesine göre okulun kapasitesine bağlı olarak A veya B senaryosuna, yani okulda bulunma veya birleşik öğretim ile eğitim yapacak. İkinci aşama, B senaryosuna göre 7, 8, 9, 11 ve 12. sınıfları içeren 21 Eylül'de başlıyor, yani iki gün okulda ve üç gün çevrimiçi ve uzaktan eğitim görecekler.

Bu süreçte vaka sayıları arttığı için eğitim ve sağlık bakanlığı öğretmenleri, öğrencileri ve velileri istenilen kurallara uymaları konusunda sürekli bildirimler ekledi.

Kosova'da eğitim nasıl devam ediyor?

EBTB yeni eğitim öğretim yılının hazırlıklarına başladı 
Eğitim, Bilim, Teknoloji ve Yenilik Bakanlığı (EBTB), 2021/2022 yeni öğretim yılına iyi bir başlangıç yapmak için hazırlıklara başladı. Bu, Eğitim Bakan Yardımcısı Edona Maloku Bërdyna tarafından düzenli basın toplantısında dile getirildi.

Pandemi nedeniyle bu zorlu öğretim yılının sona ermesinden bahsettikten sonra Bakan Yardımcısı Maloku Bërdyna, Eylül ayından itibaren öğrenme sürecinin fiziksel mevcudiyetle normal koşullarda başlayacağını umduğumuzu vurguladı. Ancak pandemi ile ilgili duruma bağlı olarak buna NIPHK ve Sağlık Bakanlığı gibi yetkili kurumlar tarafından karar verileceğini söylerken, iyi haberin öğretmenlerin yeni eğitim-öğretim yılına daha iyi hazırlanmaları için aşılarının başlamış olması olduğunu vurguladı.

\section{Araştırmanın Amacı}

Covid-19 eğitimi etkilediği kadar öğretmenleri, öğrencileri ve bir o kadar da velileri etkiledi. $\mathrm{Bu}$ araştırmanın amacı Covid-19 pandemi sürecinde verilen uzaktan eğitimin faydaları ve zararlarının, velilerin gözünden ortaya koyulmasıdır.

Araştırmanın Ana Problem Cümlesi

Velilerinin, Covid-19 salgını sürecinde verilen uzaktan eğitim hakındaki görüşleri nelerdir?

Alt Problem cümleleri

1. Uzaktan eğitim için sunulan imkanlar yeterli mi?

2. Uzaktan eğitim öğrencilerin başarını olumsuz etkiledi mi?

3. Pandemi süreci öğrencileri dijital araçları gereğinden fazla kullanmaya yöneltti mi?

4. Öğrenciler covid-19 yakalanma kaygısı yaşadı mı?

5. Uzaktan eğitim süresince velilerin sorumlulukları arttı mı?

\subsection{Arastımanın Önemi}

Covid-19 pandemisi tüm dünyayı olumsuz etkiledi. Bu pandemiden etkilenen sadece büyükler olmadı, büyükler kadar çocuklar da bu pandemiden oldukça etkilendi. Pandemi süreci öğrenciler için yorucuydu maskenin takılması, masefenin korunması, alınan sıkı tedbirler, dışarı çıkma yasağı derken tüm bu hızlı değişmelere ayak uydurmaları zordu. Tüm bunların dışında her zaman 
gördükleri yüzyüze eğitimden uzak kaldılar. Uzaktan eğitim ile yeni tanışılmamış olsa da bu kadar iç içe olunacağı tahmin edilemezdi. Uzaktan (online) eğitim çoğu öğrencinin eğitiminden geri kalmaması adına oldukça faydalı olsa da her öğrenci için aynı şeyi söylemek ne yazık ki mümkün değil. Uzaktan (online) eğitim maalesef ki her öğrenci tarafından hemen benimsenemedi. Alışma, adapte olma süreci olsun, öğrencilerin derslerde sınıflarındaykenki gibi aktif olamamaları gibi daha birçok etken bazı öğrenciler için zorlu bir süreçti. Tüm bu değişiklikler sadece öğrencileri ve öğretmenleri değil velileri de bir o kadar etkilemiştir. $\mathrm{Bu}$ dönemlerde veliler her zamankinden fazla çocuklarının eğitim sürecinde dahil edilmiştir. Bu süreçte öğrencileri daha iyi anlayabilmek, bu zorlukların üstesinden nasıl gelindiğinin araştırılması uygun görülmüştür.

\section{Yöntem}

\subsection{Araştırma Modeli}

Araştırma tarama modelinde betimsel bir çalışmadır. Çalışma nicel bir çalışma olarak tasarlanmıştır. Nicel araştırmalarda anket gibi nicel veri toplama yöntemleri kullanılır ve algılar ile olaylar doğal ortamda gerçekçi ve bütüncül bir biçimde ortaya konmaya çalışılır (Yıldırım ve Şimşek, 2005). Veriler Covid-19 pandemisi sürecinde, mesafe kurallarına uygun bir şekilde toplanmıştır.

\subsection{Evren ve Örneklem}

Araştırmanın evrenini 2020-2021 eğitim öğretim yılında, Prizren, Priştine, Mamuşa merkezlerinde bulunan "Abdyl Frasheri(PZ)", 'Emin Durak (PZ), Mustafa Baki (PZ), Elena Gjika (PR), Anadolu (MA)" Eğitim Bakanlığına Bağlı İlköğretim Okullarında Türkçe eğitim gören öğrencilerin velileri ile yapılmıştır. Örneklem ise 1. 2. 3. 4. ve 5 sınıf öğrencilerinin velileri dahil edilmiştir. Toplamda 153 veliye anket uygulanmıştır. Ayrıntılı bilgi tablo 1.1'de verilmiştir.

Tablo 4.2.1. Araştırmaya katılan bireylerin cinsiyete göre dağılımı

\begin{tabular}{lll|l} 
& Kişi & Yüzde \\
\hline Anne & 106 & 69,3 \\
\hline Baba & 47 & 30,7 \\
\hline Total & 153 & 100,0 \\
\hline
\end{tabular}


Tablo 4.2.1.' den anlaşılacağı üzere katılımcılarımızın 106'sı anne 47'si baba. Katılımcılarını 69\% anneler babalar \%30’u oluşturuyor.

Aşağıda gördügünüz tabloda araştırmaya katılan velilerin çocuklarından 33'ü 6-7 yaş, 66'sı 8-9 yaş, 54'ü 10-12 yaş aralığındadır.

\section{Tablo 4.2.3 çocukların yaşa göre dă̆ılımı}



\subsection{Verilerin Toplanması}

Araştırmada veriler, derecelendirme ölçekli sorulardan oluşan anket ile elde edilmiştir. Kişisel bilgi formu ve anket formu alanında bir öğretim üyesinin görüşüne sunulmuştur. Araştırmada kullanılan anket formu üç bölümden oluşmaktadır. Birinci bölümde, araştırmaya dahil edilen velilerin çocuklarına ilişkin demografik sorular, ikinci bölümde veli adaylarının covid-19 pandemisi sürecinde ilkokul öğrencilerine yönelik yirmi sorudan oluşan değerlendirme ölçekli soru anketi, üçüncü bölümde ise velilerin eklemek isteyebilecekleri ve onlara yön verme amaçlı birkaç soru bulunmakta. Anket soruları şu şekildedir:

1. Okullar tarafından uzaktan eğitim için sunulan imkanlar yeterliydi

2. Uzaktan eğitim için öğretmene verilen ders süresi yeterliydi. 
3. Pandemi dolayısıyla eğitimin uzaktan olması gerekliydi.

4. Sınıf ortamı olmadan da dersler rahatlıkla öğretilebiliyor.

5. Uzaktan eğitim yoluyla yapılan dersler yüzyüze yapılan dersler kadar etkili olmuyor.

6. İlkokul öğrencilerinin yüzyüze eğitim alması gerekliydi.

7. Uzaktan eğitim ile öğrenciler birçok dersten geri kaldı.

8. Teknik yetersizliklerden dolayı eğitim aksaması yaşandı.

10. Uzaktan eğitim öğrencilerin başarısını olumsuz etkiliyor.

11. Uzaktan eğitim sürecinde öğrenciler odaklanma sorunu yaşadı.

12. Uzaktan eğitim uygulamaları öğrenciyi daha aktif hale getirir.

13. Her öğrencinin derse katılabilmesi için gerekli araç-gereci vardı. (bilgisayar, telefon)

14. Pandemi süreci öğrencileri dijital araçları gereğinden fazla kullanmaya yöneltti.

15. Öğrenciler covid-19 yakalanma kaygısı yaşadı.

16. Pandemi süreci öğrencilerin sosyalleşmesini olumsuz etkiledi.

17. Öğretmen uzaktan da olsa belirlediği hedeflere ulaştı.

18. Öğretmen uzaktan eğitim süresince aile ve öğrencilerle normalden daha fazla iletişim içindeydi.

19. Veliler çocuklarının geleceğinden endişeleniyor.

20. Uzaktan eğitim süresince velilerin sorumlulukları arttı. 


\section{Bulgular}

5.1 "Uzaktan eğitim yoluyla yapılan dersler yüzyüze yapılan dersler kadar etkili olmuyor" sorusuna yönelik bulgular.

Uzaktan eğitim yoluyla yapılan dersler yüzyüze yapılan dersler kadar etkili olmuyor sorusuna veliler "Kesinlikle katılıyorum" cevapların \%62,7, "katılıyorum" cevapların \%24,2, "kısmen katılıyorum" ise cevapların \%5,2'sini oluşturuyor. Velilerin geri kalan \%7,9'luk kısmı ise uzaktan eğitimin yüzyüze eğitimden pek de bir farkı olmadığını düşünüyor olacaklar ki "katılmıyorum" ve "kesinlikle katılmıyorum" cevaplarını vermişlerdir.

Uzaktan eğitim yoluyla yapılan dersler yüzyüze yapılan dersler kadar etkili olmuyor sorsuna yönelik velilerin farklı endişeleri ve fikirleri var. Bu fikirlere yönelik aşağıda örnekler sunulmuştur.

V(A): Uzaktan eğitimin yeterli olmadığını düşünüyorum. Hazırlıksız yakalanılan bu süreçte tam bir plan program yapılamadığından ve yetersiz ekipmanlardan dolayı istenilen verimin alınamadığının kanaatindeyim.

V(B): Pandemi sürecinde dersler online olunca veli olarak hem biz hem de çocuklarımız bu sürece adapte olmamız zordu. Uzaktan eğitim, yapılan yüzyüze eğitim kadar verimli olamadı, öğrenciler birçok şeyi çok daha kolay ve daha iyi bir şekilde öğrenebilirdi. Uzaktan eğitim sürecinde öğrencilere ayrılan soru sorma zamanı kısıtlıydı ve öğrenciler birçok şeyi anlamakta zorlandıklarını fark ettim.

V(C): Uzaktan eğitimi tek yararı eğitimden tamamen kopmamış olmalarıydı.

Tablo 5.1.1. Uzaktan eğitim yoluyla yapılan dersler yüzyüze yapılan dersler kadar etkili olmuyor sorusuna yönelik yüzdeler. 


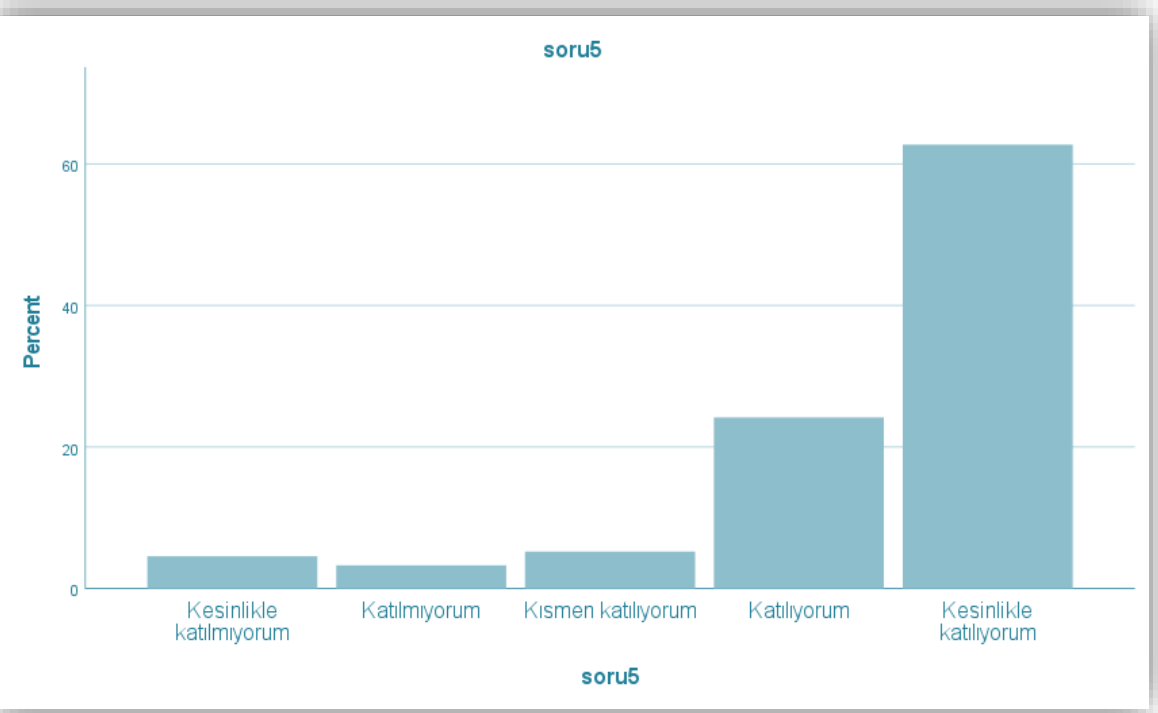

5.2 “Uzaktan eğitim öğrencilerin başarısını olumsuz etkiliyor” sorusuna yönelik bulgular.

Soruya cevap veren velilerin çoğu uzaktan eğitimin, çoçuklarının başarısını olumsuz etkilediğini düşünüyor. "Uzaktan eğitim öğrencilerin başarısını olumsuz etkiliyor" sorusuna velilerin \%45,8'i "Kesinlikle katılıyorum", \%24,8'i "Kat1lıyorum", \%12,4'ü ise "K1smen katıliyorum" cevabını vermişlerdir. Geri kalan \%17'lik kısım ise uzaktan eğitimin, çocuklarının başarısında olumsuz bir etkisi olmadığını düşünüyor.

V(D): Uzaktan eğitim çocuğumun başarısını olumsuz etkiledi. Öncelikle derslerde odaklanma sorunu yaşadı, dersler başladığında heyecanladığını, derse karşı aktifliğinin azaldığını fark ettim. Herkesin bir anda internete bağlanması internetin kesilmesine ve teknik sorunlara yol açıyordu, çocuğumun bu durumlardan sıkıldığını görüyordum.

V(E): Pandemi sürecinde çalışan bir veliyim, dersle katılmak için öğrenciler bilgisayarı kullanmak zorundaydı ve yeni okuma yazma öğrenen biri için bu durumun zor olduğunu düşünüyorum. Tabii ki bu zorluklar çocuğumun başarısını olumsuz etkiledi.

$\mathrm{V}(\mathrm{G})$ : Veli olarak pandeminin ilk süreçlerinde çok tedirgindik, pandemi sürecinde online eğitimdeki kalite bizlerde endişe yaratıyordu. Çok uzatılmadan sıkı önlemler az da olsa gevşetildi ve okullarda kısıtlı hızlı ders görülmeye yöneldiler ancak pandemi sürecindeki eğitimin kaliteli eğitim olduğu söylenemez. Ancak dünya genelinde yaşanan bu süreç böyle gerektirdiği için başka 
alternatifler düşünülemezdi. Tabii ki bu değişiklikler öğrencilerin başarısını olumsuz yönde etkiliyor.

Tablo 5.2.1 'Uzaktan ĕ̆itim öğrencilerin başarısını olumsuz etkiliyor'” sorusuna yönelik yüzdeler

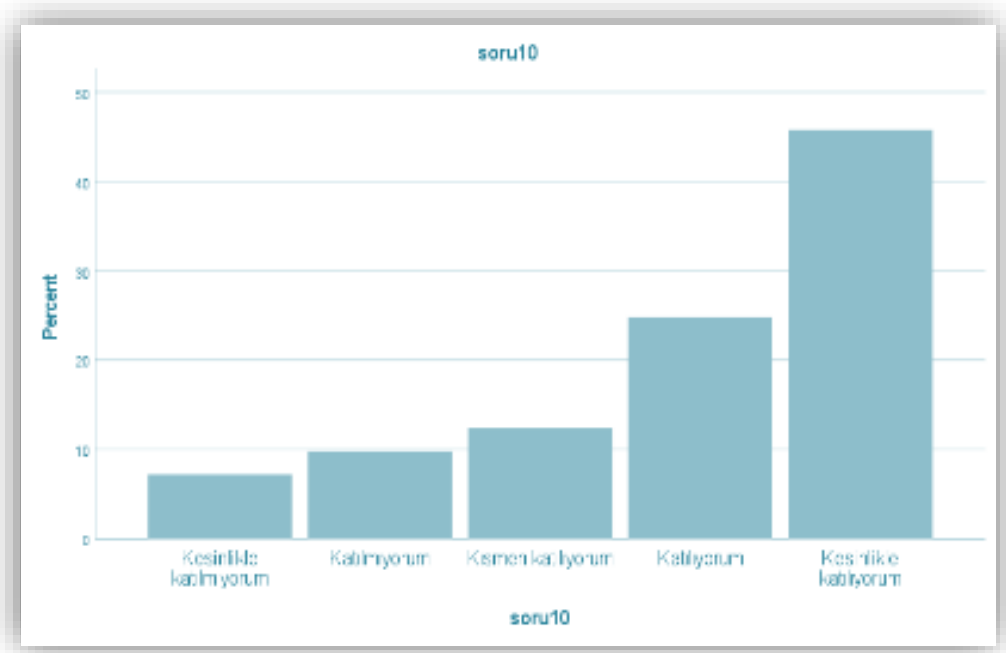

\section{3 'Öğrenciler covid-19'a yakalanma kaygısı yaşadı’’ sorusuna yönelik bulgular}

Öğrenciler covid-19'a yakalanma kaygısı yaşadı mı sorusuna veliler çoğunlukla kesinlikle katılıorum(\%34) ve katılyorum(\%34) cevabını vermişlerdir. Bunun yanı sıra velilerin \%16'sı kısmen katıldıklarını, geri kalan \%16'sı ise çocuklarının covid-19'a yakalanma kaygısı yaşamadıklarını düşünüyor.

Tablo 5.3.1 'Ö̈̆renciler covid-19'a yakalanma kaygısı yaşadı'” sorusuna yönelik yüzdeler

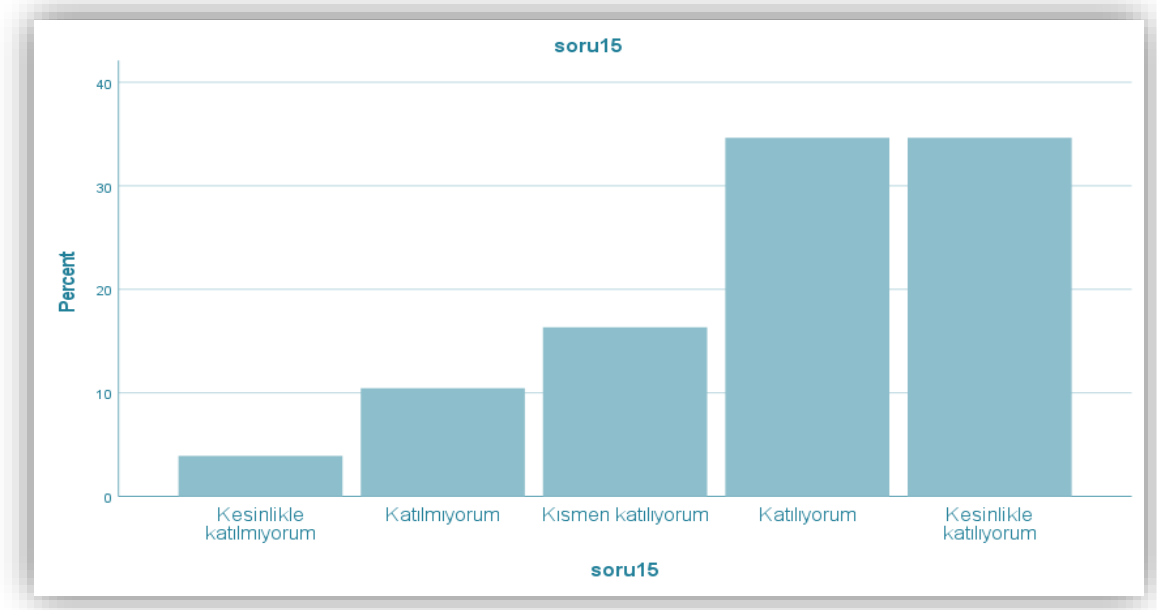




\section{Sonuç ve Öneriler}

Covid-19 pandemisi tüm dünyayı olumsuz yönde etkiledi. Sosyal mesafenin korunması gerekçesiyle derslere online olarak devam edildi. Tabii ki bu süreçte öğrenciler için en uygun ve en uygulanabilir olan fikri bulmak ve uygulamak için eğitimde farklı farklı değişikliklere başvuruldu. Bu değişikliklere tüm dünya hazırlıksız yakalandı desek yanlış olmaz. Ülkemizde pandemi nedeniyle eğitim zorunlu tatil edildikten kısa bir süre sonra hemen online eğitime başvuruldu. Veliler verilen online eğitimin asla yüzyüze yapılan eğitimin yerini almayacağının kanaatine varmaları çok da uzun sürmedi. Online eğitimin öğrencilere sağladığı avantajların, sağladıkları dezavantajlara nazaren daha az olduğu düşünülüyor. Online eğitimin sağladığı avatajları sorulduğunda ise velilerin çoğu eğitimden tamamen kopmamalarını sağladığını, hiç yoktan iyi olduğunu fakat hem kendilerine hem de çocuklarına daha fazla zorluklar getirdiğini söylüyor. Veliler okullar tarafından sunulan imkanların kısmen yeterli olduklarını düşünüyor. Online eğitim süresince öğrencilerin adapte olma sorunu yaşadıklarını, bu süreçte daha tedirgin, sınıf ortamından uzak kaldıkları için daha üzgün olmalarına ve bu yüzden de çocuklarının farklı davranışlar sergilemelerine yol açtı̆̆ııı belirtiyorlar. Online eğitim süresince derslerin kısaltılması, bu yüzden öğrencilerin birçok şeyi anlamakta zorluk yaşamasının yanı sıra zaman sıkıntısı olduğundan dolayı da soru soramama gibi ilave bir sıkıntının daha ortaya çımasına sebep oldu. $\mathrm{Bu}$ süreçte de velilerin devreye girdiğini ve anlamadıkları konularda onlara destek verdiklerini söylediler. Veliler covid-19 pandemisi sürecinde çocukların dijital araçları gereğinden fazla kullandıklarını belirtti. Bunun nedenleri sorulduğunda ise evde sıkıldıkları, sokağa çıkma yasağı, arkadaşlarını uzun süre görememeleri gibi birçok nedenin olduğunu dile getirdiler. Bu hastalık tüm insanlığın farklı düşünmesine, bazı değerlerin önemini yeniden kavramamıza neden oldu. $\mathrm{Bu}$ önemli değerlerden biri de hiç kuşkusuz ki aile oldu. Covid-19 pandemisi ve dolayısıyla da sokağa çıkma yasağı, öğrenciler ve velilerin her zamankinden daha fazla bir süreyi evde geçirmelerine ve bu süreçte de aile bağlarının güçlenmesine yol açtı. Bu bağ covid-19'un onlara getirdiği en pozitif şeylerden biri olarak görülmektedir. Pandemi dolayısıyla eğitimin, uzaktan olması gerektiği düşünülse de çoğunluk tarafından ilkokul ve özellikle 1. ve 2. sınıfların yüzyüze eğitim alması gerektiği düşünülmüştür. Bunun sebebi ise okula daha yeni başlamış ve yaşları çok küçük olan öğrencilerin daha yeni yeni okuma ve yazma öğrendikleri için online eğitimin, gerek teknolojik 
araçları kullanmakta zorluk çekmeleri olsun, gerek çalışan ailelerin her zaman çocuklarının başlarında olamamaları olsun yeterli olmadığı düşünülmüştür. Pandemi süreci çocukların agresif,sıkılgan,asosyal,isteksiz ve pasif olmaları gibi daha birçok nedene yol açmıştır. Uzaktan eğitim öğrencilerin başarısını olumsuz etkiliyor veya daha doğrusu yüzyüze eğitim kadar etkili olamıyor desek yanlış olmaz. $\mathrm{V}(\mathrm{O})$ : ' $\mathrm{Bu}$ süre zarfında çocuğumda pasiflik gözlemledim. Bazı günler online derslere bile katılmak istemiyordu. Nedenini her sorduğumda çok sıkıliyorum cevabını aldım. Halbuki benim oğlum okulunu, sınıf arkadaşlarını ve öğretmenini çok seven başarılı bir çocuktur." Veli O’nun vermiş olduğu bu cevap, öğrencilerin pandemi sürecine ve online eğitime adapte olmada nasıl zorlandıklarını açıkça belirtiyor. Çocukların sürekli evde olması tabii ki onların sosyalleşmesini olumsuz yönde etkiledi. Covid-19 pandemisi çocukları bir anda eve kapattı ve onların düzenini alt üst etti. Dolayısıyla da veliler bu açıdan her zamankinden daha fazla tedirgin hale geldiler. Tabii ki online eğitim ile az da olsa sınıf arkadaşları ve öğretmeni ile özlemler giderildi fakat sınıf ortamında yapılan konuşmalar, oyunlar, etkinlikler online eğitim ile yapılamadığından dolayı bu durum öğrencilerin sosyal hayatını olumsuz etkilemesine yol açtı. Pandemi sürecinde öğretmen veli ve öğrencilerle normalden daha fazla iletişimde bulundu mu sorusuna veliler "çoğunlukla katılıyorum" cevabını vermişlerdir. Veliler kadar öğretmenler de öğrencilerin geleceğinden endişeleniyor ve onlara daha iyi bir eğitim sunmak için elinden geleni yapıyorlar. Bu süreç sadece velinin veya sadece öğretmenin gayreti ile geçilebilecek bir süreç değil. Bu süreçte öğretmen ve veli bir olup öğrencilerin alabileceği en iyi eğitimi ve en iyi desteği sunarak bu zor sürecin daha kolay bir şekilde atlatılmasına yardımcı oluyor. Araştırmanın sonucunda, katılımcıların verdiği cevaplardan teknik yetersizliklerden dolayı eğitim aksaması yaşandığı kanaatine varılmıştır. Bunun dışında "her öğrencinin derse katılabilmesi için gerekli araç gereç var mı?" sorusuna veliler 2-3 çocuğu olan ailelerin bu süreçte zorlandıklarını çünkü ders saatlerinin aynı olduğu günlerde her çocuk için araç-gereç sağlamakta güçlük çektiklerini belirttiler. Herkes gibi öğrencilerin de covid-19'a yakalanma korkusu yaşadığı kanaatine varılmıştır. Veliler, pandemi sürecinde hijyen konusuna daha da fazla önem göstermeye başladıklarını söylediler. Hiç kuşkusuz ki pandemi sürecinde velilerin sorumluluğu arttı. Ankete katılan 153 veliden 136'sı bu zorlu süreçte velilerin sorumluluklarının arttığını düşünmektedir. 


\section{Öneriler}

Yaptığımız çalışma sonucunda Covid-19 Pandemisi sürecinde velilerin gözünden ilkokul çağındaki çocuklarla davranışlarının veya tutumlarının olumlu yönde değişmesinin gerçekleşmesi için Kosova Eğitim Bilim ve Teknoloji Bankanlığının (KEBTB) pandemiyle ilgili velilere seminer gerçekleştirmeleri önerilmektedir. Ayrıca bu eğitim öğretmenlere de hizmet içi eğitim verilmesi görüşü savunulmaktadır.

Araştırma bulgularından yola çıkarak pandemi döneminde çocukların sosyal ortamdan uzak durmaları, arkadaşlarıyla vakit geçirememeleri ve hastalığın bulaşma riskleri gözönüne alındığında ailelerin görüşlerine göre çocuklara psikolojik destek gerektiğinin vurgusu yapılmaktadır.

\section{Kaynakça}

Qi, S., Hua, F., Zhou, Z., \& Shek, D. T. (2020). Trends of positive youth development publications (1995-2020): A scientometric review. Applied Research in Quality of Life, 1-26.

Gibson, E. M., Bennett, F. C., Gillespie, S. M., Güler, A. D., Gutmann, D. H., Halpern, C. H., ... $\&$ Zuchero, J. B. (2020). How support of early career researchers can reset science in the postCOVID19 world. Cell, 181(7), 1445-1449.

Bhaduri, A., Andrews, M. G., Leon, W. M., Jung, D., Shin, D., Allen, D., ... \& Kriegstein, A. R. (2020). Cell stress in cortical organoids impairs molecular subtype specification. Nature, 578(7793), 142-148.

Bekaroğlu, E., \& Yılmaz, T. (2020). COVID-19 ve psikolojik etkileri: Klinik psikoloji perspektifinden bir derleme. Nesne, 8(18), 573-584.

DEMIR, A., \& ÇIFÇİ, F. (2020). COVID-19 PANDEMİ SÜRECINDE EGZERSIZIIN LİSE ÖĞRENCILERININ PSIKOLOJIK SAĞLAMLIK DÜZEYLERINE ETKISINININ İNCELENMESİ. SPORMETRE Beden Eğitimi ve Spor Bilimleri Dergisi, 18(3), 169-179.

ARSLAN, K., ARI, A. G., \& KANAT, M. H. (2021). COVID-19 PANDEMİ SÜRECINDE VERILEN UZAKTAN EĞİTIM HAKKINDA VELİ GÖRÜŞLERİ.

Akyüz, Y. (1982). Türk eğitim tarihi. Ankara Üniv. Eğitim Bilimleri Fak.

Doğan, S., \& Koçak, E. (2020). EBA sistemi bağlamında uzaktan eğitim faaliyetleri üzerine bir inceleme. Ekonomi ve Sosyal Araştırmalar Dergisi, 7(14), 110-124. 
Şimşek, Ş., Yıldırım, N., \& Gülgör, A. (2005). Developmental and environmental effects of the Kizildere geothermal power project, Turkey. Geothermics, 34(2), 234-251.

https://kosova.k12.tr/2360-2/ (15.07.2021 tarihinde alınmıştır.) 